\title{
Лікування доброякісних захворювань гепатикохоледоха, ускладнених обтураційною жовтяницею, з використанням антеградних ендобіліарних втручань
}

\author{
В. В. Бойко ${ }^{1,2}$, Ю. В. Авдосьев ${ }^{2}$, В. В. Макаров ${ }^{1}$ В. Г. Грома ${ }^{1,2}$, А. Л. Сочнева \\ ${ }^{1}$ Харківський національний медичний університет, \\ ${ }^{2}$ Інститут загальної та невідкладної хірургії імені В. Т. Зайцева НАМН України, м. Харків

\section{Treatment of benign diseases of hepaticocholedochus, complicated by obturation jaundice, using antegrade endobiliary interventions}

\author{
V. V. Boyko ${ }^{1,2}$, Yu. V. Avdosyev' ${ }^{2}$, V. V. Makarov ${ }^{1}$, V. G. Hroma ${ }^{1,2}$, A. L. Sochnieva ${ }^{1}$ \\ ${ }^{1}$ Kharkiv National Medical University, \\ ${ }^{2}$ Zaytsev Institute of General and Urgent Surgery, Kharkiv
}

\section{Реферат}

Мета. Аналіз результатів лікування доброякісних захворювань гепатикохоледоха (ГХ), ускладнених обтураційною жовтяницею (ОЖ), з урахуванням використання антеградних ендобіліарних втручань.

Матеріали і методи. Ретроспективно та проспективно проаналізовано результати лікування 34 пацієнтів з доброякісними захворюваннями ГХ, ускладненими ОЖ, в Інституті 32011 по 2017 р.

Результати. Для біліарної декомпресії у 15 (44,1\%) паціентів (1-ша група) застосували антеградні ендобіліарні втручання. У 19 (55,9\%) паціентів (2-га група) спроби виконати ретроградні втручання виявилися неефективними. Після біліарної декомпресії 24 (70,6\%) паціентам виконали реконструктивно-відновні операції із застосуванням розробленого способу лікування холедохолітіазу (ХЛ) (Пат. України на корисну модель №126337), 2 (5,9\%) пацієнтам з «ендоскопічно складними» формами ХЛ виконали мініінвазивні комбіновані втручання з антеградного та ретроградного доступів. Висновки. Застосовуючи антеградні ендобіліарні втручання, ми знизили частоту розвитку ускладнень біліарної декомпресії із 78,9 до 6,7\% (ускладнення констатували у 15 паціентів 2-ї та у 1 пацієнта 1-ї групи); частоту розвитку ускладнень після реконструктивно-відновних операцій $~ 52,6$ до 6,7\% (ускладнення констатували у10 пацієнтів 2-ї та у 1 паціента 1-ї групи), а також летальність з 10,5 до 6,7\% (померли 2 паціенти 2-ї та 1 пацієнт 1-ї групи).

Ключові слова: доброякісні захворювання гепатикохоледоха; обтураційна жовтяниця; антеградні втручання; ретроградні втручання; реконструктивно-відновні операції.

\section{Abstract}

Objective. To analyze the results of treatment of benign diseases of hepaticocholedochus $(\mathrm{HCH})$, complicated by obturation jaundice (OJ), taking into account the antegrade endobiliary interventions application.

Materials and methods. Retrospectively and prospectively in 2011-2017 yrs in the Institute were analyzed the results of treatment of 34 patients, suffering benign diseases of $\mathrm{HCH}$, complicated by OJ.

Results. For biliary decompression in 15 (44.1\%) patients (Group I) the antegrade endobiliary interventions were applied. In 19 (55.9\%) patients (Group II) the attempts to perform retrograde interventions have appeared ineffective. After biliary decompression in $24(70.6 \%)$ patients the reconstructive-restorational operations were performed with application of the elaborated method of treatment of the HCH diseases (Pat. Of Ukraine on purposeful model №126337), and in 2 (5.9\%) patients with «endoscopically complex» forms of choledocholithiasis the miniinvasive combined interventions, using antegrade and retrograde accesses, were conducted.

Conclusion. While applying of antegrade endobiliary interventions we have had lowered the complication rate for biliary decompression from 78.9 to $6.7 \%$ (complications were registered in 15 patients of Group II and in 1 patient of Group I); the rate of development of complications, occurring after reconstructive-restorational operations - from 52.6 to $6.7 \%$ (complications were registered in 10 patients of Group II and in 1 patient of Group I), and the lethality as well - from 10.5 to $6.7 \%$ (2 patients of Group II and 1 patient of Group I died).

Keywords: benign diseases of hepaticocholedochus; obturation jaundice; antegrade interventions; retrograde interventions; reconstructive-restorational operations.

Останнім часом зростає число пацієнтів з доброякісними захворюваннями ГХ, серед них $є$ ХЛ, який виявляють у 10 - 17\% населення розвинутих країн [1, 2].

Ендоскопічна папілосфінктеротомія та ендоскопічна холедохолітоекстракція залишаються методом вибору лікування ХЛ $[3,4]$. Однак у ряду хворих виконання ефективних втручань на великому сосочку дванадцятипалої кишки (ДПК) є неможливим, а іноді й небезпечним.
Великі розміри, незручні для маніпуляцій форма та локалізація каменів, порушення анатомії органів гепатобіліарної зони унеможливлюють ендоскопічне лікування ХЛ [5]. Такі ускладнення, як рефлюкс-холангіт, гострий панкреатит, кровотеча з папілотомної рани та вклинення кошика Дорміа, що розвиваються після невдалих або неефективних спроб ендоскопічного лікування, можуть стати фатальними $[6,7]$. 
У зв'язку із збільшенням кількості операцій з приводу жовчнокам'яної хвороби почастішало виникнення стриктур ГХ після його пошкодження під час виконання лапароскопічної або відкритої холецистектомії. ОЖ, хронічний рецидивуючий холангіт і печінкова недостатність значно погіршують результати лікування [8].

Крім ХЛ і стриктур ГХ, тяжкими захворюваннями органів гепатобіліарної зони вважають стриктури біліодигестивних анастомозів, які мають запальний характер. У переважної білышості пацієнтів дана патологія є наслідком пошкодження жовчних проток, неправильного їх дренування, грубих хірургічних маніпуляцій на протоках і триваючої пухлинної інвазії [9].

Вибір хірургічної тактики лікування та способу відновлення відтоку жовчі у пацієнтів 3 «ендоскопічно складними» формами ХЛ, стриктурами ГХ і біліодигестивних анастомозів досі залишається невирішеною проблемою хірургії органів гепатобіліарної зони. Після реконструктивно-відновних операцій, виконаних пацієнтам, які мають ОЖ, частота ускладнень становить 10-48\%, летальність $-3,2-28,2 \%$ [10].

Впровадження в клінічну практику антеградних ендобіліарних втручань дало змогу значно спростити доступ до жовчовивідних проток. У ряду пацієнтів, коли немає технічної можливості або неефективно застосовувати ретроградні втручання, антеградні ендобіліарні втручання уможливлюють здійснити декомпресію і санацію жовчовивідних проток, нівелювати синдром ОЖ, усунути явища холангіту, підготувавши в такий спосіб пацієнтів до реконструктивно-відновних операцій з мінімальним для них ризиком. Комбіноване використання антеградних та ретроградних втручань дає змогу успішно лікувати «ендоскопічно складні» форми ХЛ мініінвазивним способом, що особливо актуально у пацієнтів літнього віку та з високим анестезіологічним ризиком [11 - 14].

Мета дослідження: аналіз результатів лікування доброякісних захворювань ГХ, ускладнених ОЖ, з використанням антеградних ендобіліарних втручань.

\section{Матеріали і методи дослідження}

У дослідження включено 34 пацієнти з доброякісними захворюваннями ГХ, ускладненими ОЖ, які перебували на лікуванні в Інституті з 2011 по 2017 р. Профіль дослідження відповідав міжнародним вимогам CONSORT i мав відповідний дизайн - ретроспективне і проспективне рандомізоване клінічне дослідження, в якому порівнювали результати лікування пацієнтів з доброякісними захворюваннями ГХ, ускладненими ОЖ.

Всі етичні принципи дотримані. Дозвіл на проведення дослідження надала етична комісія Харківського національного медичного університету (протокол засідання № 2 від 13.03.2018 р.). Від усіх пацієнтів отримано письмову інформовану згоду на використання результатів лікування для дослідження.

ХЛ був причиною ОЖ у 21 (61,8\%) хворого, стриктури ГХ - у 6 (17,6\%), біліодигестивних анастомозів - у 7 (20,6\%) пацієнтів. Вік пацієнтів варіював від 33 до 88 років, середній вік становив 65 років. Чоловіків було 9 (26,5\%), жінок - 25 (73,5\%).
Пацієнтів розподілили на дві групи. Першу групу (основну) склали 15 (44,1\%) пацієнтів, у лікуванні яких використовували антеградні ендобіліарні втручання. У подальшому їм виконані реконструктивно-відновні оперативні втручання, комбіновані мініінвазивні операції з антеградного та ретроградного доступів або ж антеградні ендобіліарні втручання стали єдиними в їхньому лікуванні. До 2-ї групи (порівняльної) увійшло 19 (55,9\%) пацієнтів, у яких спроби виконати ретроградні втручання були невдалими та яким у подальшому виконали реконструктивно-відновні операції.

Обидві групи мали однорідний розподіл за співвідношенням статі, віку і досліджуваної нозології. Умови спостереження для двох порівнянних вибірок збігалися. Достовірність відмінностей між групами визначали за непараметричним критерієм $\chi^{2}$. Критичним вважали рівень значущості, що дорівнював 0,05.

За тривалістю ОЖ визначали згідно з класифікацією О. В. Смирнова (1974): гостра - до 10 днів, гостра тривала - від 10 до 30 днів, хронічна - понад 30 днів [15]. Гостру ОЖ спостерігали у 8 (53,3\%) пацієнтів 1-ї та у 14 (73,7\%) - 2-ї групи, гостру тривалу - у 2 (13,3\%) та 3 (15,8\%), хронічну - у 5 (33,3\%) та 2 (10,5\%) пацієнтів відповідно.

Цифрові дані опрацьовували статистично, використовуючи персональний комп'ютер та програми Excel 2010, Statistica 10.0. Репрезентативність дослідження оцінювали за критерієм Манна-Уітні, t-критерієм Ст'юдента і критерієм $\chi^{2}$, довірчі інтервали - за методом Клоппера-Пірсона. Результати вважали статистично значущими, коли значення р були менше 0,05.

\section{Результати}

У перші 2 доби з моменту госпіталізації всім пацієнтам 1-ї групи за наперед відомої невдалої спроби або неможливості виконання ендоскопічної папілосфінктеротомії, обумовленої технічними або анатомічними особливостями, виконували черезшкірне черезпечінкове холангіодренування (ЧЧХД) або черезшкірну черезпечінкову холецистостомію під рентгенологічною та ультразвуковою навігацією з метою декомпресії жовчовивідних проток. Холангіодренаж вдалося встановити 3 (20\%) пацієнтам, у яких розширення внутрішньопечінкових проток не перевищувало 5 мм.

У подальшому 5 (33,3\%) пацієнтам виконали реконструктивно-відновні операції, 2 (13,3\%) - комбіновані мініінвазивні втручання з антеградного та ретроградного доступів. У решти 8 (53,3\%) пацієнтів антеградні втручання були єдиним методом лікування з огляду на їх достатність або через високий анестезіологічно-операційний ризик та тяжкість супутньої патології.

Ускладнення, пов'язані безпосередньо з виконанням чЧХД, спостерігали у 1 (6,7\%) хворого, а саме міграцію холангіодренажа.

У 15 (78,9\%) пацієнтів 2-ї групи виникли ускладнення, пов'язані безпосередньо з виконанням ендоскопічної папілосфінктеротомії. Висхідний холангіт внаслідок дуоденобіліарного рефлюксу у разі невдалої спроби вилучити конкремент, діаметр якого був більший, ніж діаметр гХ дистальніше місця обструкції, розвинувся у 4 (21,1\%) 
пацієнтів. Транзиторну гіперамілаземію спостерігали у 3 (15,8\%) пацієнтів. Це ускладнення було через 1-2 доби усунуто шляхом застосування лікувальних доз інгібіторів протеаз. Напади гострого панкреатиту у 2 (10,5\%) пацієнтів також усунули консервативними методами. Кровотеча з папілотомної рани виникла у 1 (5,25\%) пацієнта. Її спричинили, крім величини розрізу, порушення коагулюючих властивостей крові на тлі тривалої ОЖ. Кровотечу зупинили промиванням зони розрізу холодним фізіологічним розчином або розчином амінокапронової кислоти через ендоскоп. Потреби у цілеспрямованій гемостатичній терапії і гемотрансфузії не було. Вклинення кошика Дорміа сталося у 5 (26,3\%) хворих. Їм виконали холедохолітотомію, дренування загальної жовчної протоки (ЗЖП) за Холстедом-Піковським у першу добу від моменту виконання ендоскопічної папілосфінктеротомії.

В обох групах після біліарної декомпресії жоден пацієнт не помер.

Після біліарної декомпресії 26 (76,5\%) пацієнтам були виконані реконструктивно-відновні операції та мініінвазивні втручання. Супрадуоденальну холедохолітотомію, холедохолітоекстракцію, дренування ЗЖП виконали 18 (52,9\%) пацієнтам, оскільки папілотомного отвору було досить для нормалізації відтоку жовчі за відсутності для цього перешкод. У 3 (8,8\%) пацієнтів сформували холедоходуоденоанастомоз, у (8,8\%) - гепатикоєюноанастомоз на петлі тонкої кишки, виключеній за Ру. У 2 (13,3\%) пацієнтів 3 «ендоскопічно складними» формами ХЛ застосовані комбіновані мінінвазивні втручання з антеградного та ретроградного доступів.

Реконструктивно-відновних операцій було значущо більше у $2-$ й групі $(\mathrm{p}<0,01)$. Значення критерію $\chi^{2}$ дорівнює 18,451 , тоді як критичне значення критерію $\chi^{2}$, коли $\mathrm{p}<0,01$, дорівнюе 13,277.

Ускладнення після реконструктивно-відновних операцій виникли у 1 (6,6\%) пацієнта 1 -ї групи. У нього післяопераційний період мав тяжкий перебіг: виникла внутрішня жовчна нориця на тлі печінкової недостатності, яку усунуто. Пацієнта виписали зі стаціонару на 19-ту добу після операції. У 2-й групі ускладнення після реконструктивно-відновних операцій виникли у 10 (52,6\%) пацієнтів. Зовнішні жовчні нориці, проявом яких було витіканням жовчі по дренажу правого підребер'я та які сформувалися у 4 (21,1\%) пацієнтів, закрилися самостійно на тлі проведеної консервативної терапії і не потребували втручань. Гнійний холангіт, який розвинувся у 2 (10,5\%) пацієнтів, вилікували шляхом застосування антибактеріальних засобів і санації жовчовивідних проток розчинами антисептиків. Прогресування печінкової недостатності констатували у 2 (10,5\%) пацієнтів, яких вилікували так само консервативними заходами. Розвиток реактивного плевриту спостерігали у 2 (10,5\%) пацієнтів. Їм з успіхом застосували плевральні пункції.

У 2 (13,3\%) пацієнтів 1-ї групи виконали комбіновані мініінвазивні втручання з антеградного та ретроградного доступів. Нами розроблено спосіб лікування ХЛ (Пат. України на корисну модель №126337), мета якого мінімізація кількості ендоскопічних втручань, а також кількості відкритих оперативних втручань, які необхідно виконувати з приводу ХЛ.
Техніка виконання втручання. Після невдалої спроби видалення конкрементів ендоскопічним шляхом виконують черезшкірні черезпечінкові холангіографію та холангіодренування. Літоекстракцію здійснюють зводячи конкременти за допомогою двохпросвітного балонного катетера у просвіт ДПК через папілотомний отвір антеградно під контролем рентген-телебачення.

Наводимо клінічні спостереження.

Хворий А., 58 років, госпіталізований у клініку Інституту 3 діагнозом: постхолецистектомічний синдром, ХЛ, гостра ОЖ. Діагноз верифіковано за даними ультразвукового дослідження (УЗД) органів черевної порожнини: діаметр ЗЖП - 15 мм, діаметр конкремента - 13 мм. Виконано дуоденоскопію, ендоскопічну ретроградну холангіопанкреатографію, ендоскопічну папілосфінктеротомію, спробу механічної холедохолітотрипсії та холедохолітоекстракції, яка не мала успіху, оскільки сталося вклинення кошика Дорміа. Конкремент не був вилучений. Паціенту виконано черезшкірні черезпечінкові холангіографію та холангіодренування, встановлено рівень біліарного блоку, а потім конкремент зведено у просвіт ДПК крізь папілотомний отвір за допомогою двохпросвітного балонного катетера. Катетер проводили по провіднику проксимальніше конкремента у здутому стані, роздували його до 10 мм в діаметрі та виштовхували конкремент балоном в отвір ДПК. Операцію завершено виконанням холангіографіїтіні конкрементів не визначали, контрастна рідина вільно надходила до ДПК. Холангіодренаж залишено. На 4ту добу виконано контрольну холангіографію через холангіодренаж. Спостерігали зменшення діаметра жовчних проток до норми, тіні конкрементів не визначалися, контрастна рідина вільно надходила до ДПК. Холангіодренаж видалено. На 5-ту добу після операції пацієнта у відносно задовільному стані виписано із стаціонару.

Хворий М., 71 рік, госпіталізований у клініку Інституту з діагнозом: жовчнокам'яна хвороба ІІ стадії, гострий холецистит, ХЛ, гостра тривала ОЖ. Також у пацієнта була супутня кардіальна та ендокринна патологія у стадії декомпенсації. За допомогою УЗД органів черевної порожнини у жовчному міхурі виявлені множинні різнокаліберні конкременти діаметром від 5 до 12 мм, стінка жовчного міхура товщиною до 3 мм без ознак деструкції. ЗЖП діаметром до 12 мм, в ії просвіті містяться два конкременти діаметром 5 та 6 мм та біліарний «сладж». Виконано дуоденоскопію та папілосфінктеротомію. Операцію зупинено, оскільки почалась кровотеча з папілотомної рани, яку зупинено інтенсивною гемостатичною терапією. Через 3 доби здійснено контрольну дуоденоскопію, кровотечі не було. 3 урахуванням тяжкості стану хворого та наявності ускладнень після папілотомії прийнято рішення про спробу вилучення конкрементів шляхом їх зведення у ДПК через папілотомний отвір антеградним шляхом. Операцію виконали успішно, після вилучення конкрементів здійснили санацію ГХ розчинами антисептиків, тіней конкрементів не виявили, контрастна рідина вільно потрапляла в ДПК. Контрольна холангіографія на 3-ту добу: картина та сама. Холангіодренаж видалено. Оскільки приступ гострого холециститу знято консервативними заходами, а операційний ризик був високий через тяжкість 
стану хворого та його вік і не було життевих показань до виконання наступної лапароскопічної холецистектомії, від неї відмовилися. Хворий виписаний на 5-ту добу після останньої операції.

Загальна летальність в обох групах становила 8,8\%. У 1 -й групі помер 1 (6,7\%) хворий. Причиною смерті стала гостра серцево-судинна недостатність. У 2-й групі померли 2 (10,5\%) хворих. Причинами їх смерті стала поліорганна недостатність 3 переважанням печінково-ниркової недостатності, а також гостра серцево-судинна недостатність.

\section{Обговорення}

Основною метою мініінвазивних втручань є покращення стану пацієнта, тобто зменшення інтоксикації та гіпербілірубінемії, ліквідація холангіту та попередження розвитку печінкової недостатності. У деяких хворих можливо мініінвазивними втручаннями замінити відкриті операції, усуваючи не тільки ОЖ, а й ії причину - конкременти ГХ [3, 14].

Антеградні ендобіліарні втручання є універсальним варіантом первинного втручання у пацієнтів 3 «ендоскопічно складними» формами ХЛ, стриктурами біліарного тракту, оскільки, крім адекватної біліарної декомпресії та прямого контрастування жовчовивідних шляхів, вони розширюють можливості вибору найбільш ефективної тактики лікування [12].

Єдиним протипоказанням до виконання антеградних ендобіліарних втручань вважають виражену гіпокоагуляцію, індикатором якої є рівень протромбінового індексу - не менше 50\% [7]. 3 огляду на ризик розвитку неконтрольованої гемобілії на тлі порушень згортання крові у бік гіпокоагуляції, застосування ЧЧХД намагалися уникати.

Якщо немає можливостей застосувати ендоскопічні способи для лікування доброякісних захворювань ГХ, ускладнених ОЖ, загальноприйнятим вважають виконання стандартних «відкритих» операцій - чи то відновних, таких як супрадуоденальна холедохолітотомія, холедохолітоекстракція, чи то реконструктивних, таких як холедоходуоденостомія, холедохоєюностомія. Виконані в умовах гіпербілірубінемії і/або гнійного холангіту, вони супроводжуються високим ризиком розвитку ускладнень і високою летальністю. Виконання попередньої біліарної декомпресії запобігає розвитку ускладнень в післяопераційному періоді [16]. Після застосування антеградних ендобіліарних втручань у плановому порядку за наявності показань ми виконували реконструктивно-відновні операції, намагаючись зберегти холангіодренаж, що в післяопераційному періоді попереджувало можливе наростання біліарної гіпертензії та захищало біліодигестивний анастомоз від неспроможності.

\section{Висновки}

1. Застосовуючи антеградні ендобіліарні втручання, ми знизили частоту розвитку ускладнень біліарної декомпресії з 78,9 до 6,7\%, частоту розвитку ускладнень після реконструктивно-відновних операцій з 52,6 до 6,7\%, летальність $з$ 10,5 до 6,7\%.

2. Антеградними ендобіліарними втручаннями поки ще неможливо замінити ендоскопічне та стандартне оперативне лікування доброякісних захворювань ГХ, проте вони $є$ його альтернативою на етапі біліарної декомпресії.

\section{References}

1. Nychytailo MYu, Grubnik VV, Lurin IA, Ogorodnik PV. Videoendoscopic diagnostics and minimally invasive surgery of choledocholithiasis. Kyiv: VSI "Medicine"; 2013;295 s. [In Russian]

2. Ogorodnyk PV, Kolomiytsev VI, Kushniruk OI, Deinychenko AG, Boyko OG. Endoscopic drainage of biliary system in acute obstruction of common bile duct. Clinical Surgery; 2013;8:24-9 [In Ukrainian];

3. Da Vee T, Garcia JA, Baron TH. Precut sphincterotomy for selective biliary duct cannulation during endoscopic retrograde cholangiopancreatography. Ann Gastroenterol; 2012; 25(4):291-302. PMID: 24714256

4. Shim CS. How should biliary stones be managed? Gut and Liver. 2010 Jun 30;4(2):161-72. doi: 10.5009/gnl.2010.4.2.161.

5. Stefanidis G, Viazis N, Pleskow D, Manolakopoulos S, Theocharis L, Christodoulou C, et al. Large balloon dilation vs. mechanical lithotripsy for the management of large bile duct stones: A prospective randomized study. Am J Gastroenterol. 2011 Feb;106(2):278-85. doi: 10.1038/ ajg.2010.421.

6. Attasaranya S, Fogel EL, Lehman GA. Choledocholithiasis, Ascending Cholangitis, and Gallstone Pancreatitis. Med Clin North Am. 2008 Jul;92(4):925-60, x. doi: 10.1016/j.mcna.2008.03.001.

7. Alekseev NA, Snigirev JV, Taraskina EB, Modzelevskaya SM, Birsh AM. Laparoscopic and minilaparatomy surgeries in the treatment of cholecystocholedocholithiasis. Annals of surgical hepatology; 2012;17(3):759 [In Russian].

8. Tantia O, Jain M, Khanna S, Sen B. Iatrogenic biliary injury: 13.305 cholecystectomies experienced by a single surgical team over more 13 years. Surg. endosc. 2008;22:1077-86 doi:10.1007/s00464-007-9740-8.

9. Saidi RF, Elias N, Ko DS, Kawai YT, Markmann J, Cosimi AB, et al. Biliary reconstruction and complications after living-donor liver transplantation. HPB (Oxford). 2009;11:505-9. doi:10.1111/j.14772574.2009.00093.x.

10. Nichitailo ME, Skums AV. Damage of the bile ducts in cholecystectomy and their consequences. Kiev: "Makkom"; 2006. 344 s. [In Russian]

11. Pomerantz BJ. Biliary Tract Interventions. Tech Vasc Interv Radiol. 2009 Jun;12(2):162-70. doi: 10.1053/j.tvir.2009.08.009.

12. Covey AM, Brown KT. Percutaneous Transhepatic Biliary Drainage. Tech Vasc Interv Radiol. 2008 Mar;11(1):14-20. doi:10.1053/j. tvir.2008.05.003.

13. Tazuma S. Epidemiology, pathogenesis, and classification of biliary stones (common bile duct and intrahepatic). Best Pract Res Clin Gastroenterol. 2006;20(6):1075-83. doi:10.1016/j.bpg.2006.05.009

14. Okuno M, Iwashita T, Yasuda I, Mabuchi M, Uemura S, Nakashima M, et al. Percutaneous transgallbladder rendezvous for enteroscopic management of choledocholithiasis in patients with surgically altered anatomy. Scandinavian Journal of Gastroenterology. 2013 Jun 19;48(8):9748. doi: $10.3109 / 00365521.2013 .805812$.

15.Smirnov YeV. Surgeries on biliary tracts. Leningrad; 1974; 238. [In Russian].

16. Addlev J, Mitchell IJ. Advances in the investigation of obstructive jaundice. Curr Gastroenterol Rep. 2012 Dec;14(6):511-9. doi: 10.1007/ s11894-012-0285-1. 